\title{
TWO FRAGMENTS OF AN IRISH ROMANCE OF THE HOLY GRAIL.
}

The following short fragments, the existence of which was long ago pointed out by Nettlau, ${ }^{1}$ ) are preserved in the Franciscan library at Dublin on two stray leaves of parchment, probably dating from the fifteenth century. I made a copy of them in the summer of 1901, when looking up various Irish romances in the Dublin libraries, and it seems worth while to have them printed for the convenience of any scholars who may hereafter be occupied with Irish versions of the story of the Holy Grail.

So far as I know, only two other Irish texts on this subject have been cited: ${ }^{2}$ ) that in MS. Stowe 992 (now R. I. A., D. 4. 2), from which Nettlau printed excerpts in the Revue Celtique $\mathrm{X}, 185 \mathrm{ff}$., and that in MS. Rawlinson B. 512, which is briefly described by Stokes in The Tripartite Life of Saint Patrick, p. XXXVIII. The relation of these to each other and to the fragments printed below remains to be investigated, though in Nettlau's opinion the Franciscan and Stowe texts 'probably represent the same translation'. The exact determination of the source of the Irish Grail romance, or romances, must also be deferred until the longer copies have been published. In the

1) Rev. Celt. X, 187. In his brief examination of the leaves Nettlau failed to observe that they form not one continuous fragment, but two with a gap of one leaf (apparently) between them. He also read them in the wrong order, and they have since been bound up so as to perpetuate this mistake. I consequently print as the 'First Fragment' the contents of the second leaf.

2) Cf. Zimmer, Gött. Gel. Anz. 1890, p. 503. 
mean time the following pages will serve very well as a specimen of the language and style of the translation. The episode here related is the same as that treated in the French prose romance La Queste del Saint Graal (edited by F. J. Furnivall, 1864), pp. 157-160 and 165-168; and somewhat more briefly in Malory's Morte Darthur (Sommer's edition), pp. 676-683. For the corresponding passage of the Welsh redaction, ' $Y$ Seint Greal', see Williams's Selections from the Hengwrt MSS., vol. I, pp. $102-110$.

My copy of the Irish text is intended to be exact. There are in the original numerous inconsistencies, not to say errors, in the matter of initial mutations, accents, spelling, and the like; but no attempt is made to correct them. The translation is rather literal, sometimes following the Irish more closely than is consistent with good English sentence structure.

It gives me much pleasure to acknowledge the courtesy with which the privileges of the Franciscan library were extended to me by the reverend custodian, Father 0' Reilly.

\section{First Fragment.}

(page 1) Don taibh eile de ridire óc ildelbach 7 ainner alaind ilcrothach ica h-ecniuch $u d h$ aici, 7 si ac guidhi Muire imma furtacht 7 ima h-oighe do coimet. Otcondaircc in maighden Sir Boos ${ }^{1}$ ) secci, ro gáir 7 ro grech fair dáigh co tisedh dia cobair ria siu no coilltea a h-oighi 7 a h-æntuma. Ro boi Sir Boos eter da trom indsin; uair dia $n$-digsedh hi fortacht a brathar, ba derb lais nach beradh for in inghin cen truailledh a h-oighe; 7 dia m-badh hi in ingen no indsaighfedh cetus, ba h-ecal lais cen breith for Liuinel beo doridhisi. Is fair ro chinn Sir Boos dul a fhortacht na maigdine fortus, 7 rogab for guidhe in coimdedh co dicra cen bas d-fhagbail do Liuinel nocu toirsedhsom for cula doridhisi dia furtacht. Ro greis Sir Boos in t-ech andegaidh an ridire, 70 rainic i $n$-imfloicsi do ro fhuacair

1) Nettlau expanded this into $B o[r t]$. But Boos is written out plainly several times in these two fragments, and the form is also found in Stokes's citations from MS. Rawlinson B. 512 (Tripartite Life, p. XXXVIII) and in Nettlau's own excerpt from the Stowe MS. 992, fol. 41 (Rev. Celt. X, 185). In the translation I have adopted Malory's form Bors. 
comrac fair, mina fhacbad an inghin. Ro tindta in ridire fri Sir Boos, 7 ro léic in inghin uadha, 7 ro comhraic fris, 7 ni fatta ro ansat a comtrom comraic, uair ro chinn Sir Boos fairseom co tarat aladha doimne dilegis fair, co ro leac dia eoch he co raibe ina fænlighi foithi. O ro furtachtaiged in inghen, ro gaidh Sir Boos ima cur imach isin maighin o tucadh hi. Is ann $\sin$ ro thócaibh Sir Boos in maighdin for ech in ridire gonta, 7 ro fhacuibset in ridiri ic snighe a fhola indsin, 7 ro imtighset rompa for iul na h-ingine; 7 ro fhiarfacht Boos scela don ingin i. coich in ridive ro imbir anforlann 7 ecen furri. 'Is brathair focus dam-sa he co demin', or in ingen, ' 7 día $\mathrm{n}$-dernadh in gnim ro fhuapair, ro curfithe u. c. ridire fo gin gai 7 claidibh hi cinaidh mo sharaigthi-si ria cenn sechtmhaine, 7 no h-imbertha oighedh esanorach fair uadein, 7 no ragadh a anum $\mathrm{i}$ pein shuthain ifirnd tria bitha. A m-batar for a $n$-imraitib condfacatar dá ridire dec armdha edighi a n-docum for lurg na h-ingine fiarlæit na foraisi; 7 ro forbailtighset rempi co mór iarna faicsin, 7 ro erail in ingen forru-som onoir 7 armitiu dethidech do tabairt do Sir Boos ar in fhoiridin dorat furri-si. Doronsat na ridire sin amal is dicra ro fhétsat, 7 ro gaidhset he con dighsed leo daig co fagbhadh anoir 7 dethiti ocu-somh, 7 co ronadmtais a cumann 7 a catach fris. Ro gaid Sir Boos forru-som imdecht do lecadh do, uair nir 1 ) bo mian lais arisem tria bithu no go fhaghbadh in ni robói ica iarraidh i. in soidech noib. Rochedaigset na ridire do Sir Boos imdecht, osedh ba tol do, 7 rocuirset a $m$-bennachtain lais; 7 rogaid in ingen fair toighecht dia fis doridhisi cipe tan tisad for culu on t-shoidech noib. Ro gell Sir Boos disi sin acht co roisedh lais, 7 ro imtigh iarsin 7 do dechaidh for iarraidh a brathar i. Liuinel, 7 ro gab ic fegadh secha i cetaraird na foraisi dia fhis in fhaicfedh he 70 nach facca ro gab ic estecht for cech leth de dia fhis in cluinfedh Sir Liuinel ica malairt 7 ica mudhugudh i cuil ecin din forais; 7 o nach cual $a$ is ,edh (page 2) [bai .... nach $]^{2}$ ) faigbedh a scela tria bithu.

Ro gab Sir Boos remi in co $[\mathrm{ar} . . . \ldots \ldots$. a remhi, 7 ni cian do dechaidh in tan itchondairce senoir foir $[\ldots \ldots$.

1) nir is written above the line.

2) The writing is badly obscured in the upper left-hand corner of this page. 
crabaidh for eoch dub dia indsaigidh, 7 rofhiarfacht scela do Sir Boos .i. [cinus ... oi] occai no can do uadhein. Ispert-som ba he Sir Boos de Frangcaib he, 7 is [ic iar]raidh a brathar .i. Sir Liuinel ro boi, uair itcondarce he eter dis ridire [ica] malairt 7 ica mudhugudh o chianaib, olse. 'A Sir Boos', ol in senoir, 'nir [ba] coir duit dogra na diprocoit fort, uair is derchaine do neoch doilghius fair im na [h] esbadhaib sæghalla, uair is $e d$ is coir do cechoen a taccradh dfulang ar seirc in coimdedh. Occus ata ni aile fos', olse, 'itber-sa fritt .i. inní atai iarraidh fogebha a fhiss ocam-sa co $m$-ba soleir duit o shuilib corpardha he.' Otcuala Sir Boos na haithesca-sain, ba derb lais conid bas foruair Sir Liuinel, 7 ba moiti a thoirrsi 7 a truaighnemeli an airet-sain dia scel $a$ dfhaghbhail, 7 ro boi sist cen labra cen ermasin ${ }^{1}$ ) ar uaman in sceoil. 0 ro ermais labhra fa deoigh ro gaidh Sir Boos for in senoir corp a brathar do taiselbad do, masa marbh ro boi, a comhair a adhnaicthi do-som co $n$-anoir co $n$-ermhitin amal uadh chubaidh fri h-uaisli a chineil 7 fria degairilliudh fein. 'Déch sechat', ol in senoir, 'dia fhis cret itcife.' Ro dech Sir Boos secha 7 itcondaircc araile corp marbh ina fhænlighe ina fhiadhnasi, 7 sé nuachrechtnaigthi fuillrigthi amal bid an uairsin fogabadh bas; 7 indalle Sir Boos ba hi delb Sir Liuinel ro bui fair. Ro nuidhigh a cuma 7 a toirrsi ica fhaicsin-sin for Sir Boos co ro thoit [hi] 2) taisi 7 tamhneoill fair, co $m$-bói fri h-athaidh fhota sinti fri lar amal cech marb aile. 0 ro eraigh asin neoll-sin ro fhiarfacht don t-senoir coich ros-marb Sir Liuinel, ardaig a digalta do-som, 7 ni ro indis do. Ro gab Sir Boos ic accáine co mor andegaidh a bhrathar 7 is ed itberedh: 'Uch, a Liuinel, a bhrathair inmhain 7 a choceile carthanaigh, dursan duit amal rom-facbais am-ænar, uair ba th mo coimedaig in cech ecendail gabaid, 7 ba tu mo cumthach tairisi an duintib righ in tan teghmis for cuairt amsaine a cathraig Camaloit hi crich echtarcheineoil, conidh aire-sein is deghail cuirp fri h-anmain lim-sa scaradh frit a cein no marmais dib linaibh; 7 on lo ro deghlais frim ni fhuil do snimh form acht coimet mo anma fein

1) I am doubtful about the exact translation of ermasin. If it is the same word as ermaissiu discussed by Atkinson, On Irish Lexicography, p. 25, it is used here in a sense somewhat different trom the meanings it bears in the passages there cited. Professor Meyer has called my attention to other instances of its use quoted in his Contributions, under airmasiu.

2) $h i$, instinctly written above the line. 
o sund immach.' Asa h-aithli sein ro tócaib Sir Boos in corp eter a dibh lamhaib 7 ro chuir an dillait an sdeda he, 7 ro ataig for an seanoir a seoladh co aroile mainistir ecin inan adhnaicfedh corp a brathar. Ispert in senoir friseom boi deirtech bec ina comfhocus 7 ba tai[tt].1)

\section{Translation.}

On the other side of him a knight, young and very handsome, and a damsel, fair and very comely, suffering violence at his hands and begging Mary to help her and preserve her purity. When the maiden saw Sir Bors going past, she called and cried aloud to him to come to her aid before her purity and her virginity should be lost. Then was Sir Bors between two difficulties: for if he should go to the help of his brother, it was clear to him that he would not find the maiden with her honor unsullied; and if he should go first to the maiden, he had fear of not finding Lionel again alive. Sir Bors determined to go first to the help of the maiden, and he began to pray to the Lord fervently that Lionel might not meet death before he should come back again to help him. Sir Bors spurred his horse after the knight, and when he came very near he offered him battle, unless he would leave the maiden. The knight turned to Sir Bors, and released the maiden, and fought with him; and not long did they remain in equal combat, for Sir Bors overcame him and inflicted deep, incurable wounds upon him, so that he fell from his horse and lay supine beneath it. When the maiden was rescued, she asked Sir Bors to take her to the place whence she had been brought. Then Sir Bors lifted the maiden upon the horse of the wounded knight, and they left the knight bleeding there, and proceeded upon the maiden's course; and Bors asked news of the maiden, namely, who the knight was that had used force and violence upon her. 'He is a near' kinsman to me', said the damsel; 'and if he had accomplished the deed he attempted, five hundred knights would have been slain at the point of spear and sword on account of my insult before the end of a week, and dishonorable death would have been inflicted on him himself, and his soul would have gone into

1) Perhaps taig-. The word seems to be incomplete. 
the everlasting pain of hell forever.' While they were discoursing, they saw twelve knights, armed and equipped, approaching in pursuit of the maiden through the forest; and they rejoiced greatly at the sight, and the maiden bade them show honor and careful respect to Sir Bors because of the help that he had brought her. The knights did this as heartily as they could, and they begged him to go with them that he might receive honor and care at their hands, and that they might pledge their comradeship and alliance to him. Sir Bors begged them to give him leave to depart, for he did not wish to delay long before finding that which he was seeking, namely, the Holy Grail. The knights granted Sir Bors leave to go, since it was his wish, and they gave him their blessing; and the maiden begged him to come to see her again whenever he should return from the Holy Grail. Sir Bors promised her this, provided that he should attain his purpose, and then he set forth, and went to seek his brother, namely Lionel; and he began to look about him in the four quarters of the forest to learn if he could see him; and when he did not see him, he began to listen on every side to see if he could hear Sir Lionel being hurt and disabled in any corner of the forest; and when he did not hear, this [was his fear], that he should never get news of him.

Sir Bors went on his way ........ and he did not go far before he saw an old man ........ [in religious guise (?)] approaching on a black horse, and he asked news of Sir Bors, namely, what [was his business (?)] and whence he came. He said that he was Sir Bors of the French, and that he was seeking his brother, Sir Lionel, because he had not long since seen him between two knights who were wounding and disabling him, said he. ' 0 , Sir Bors', said the old man, 'sorrow and lamentation are not fitting for thee, for it is despair to anyone if he grieves for the losses of this life, since it is fitting for everyone to strive to endure them for the love of the Lord. And still one thing more', said he, 'I will say to thee: the thing thou art seeking, from me thou shalt have knowledge of it, so that it shall be clear to thee with thy bodily eyes.' When Sir Bors heard these answers, it was clear to him that Sir Lionel had met his death, and the greater was his sorrow and his pitiable anxiety at that time to get news of him, and he was a while without speech and without strength (?) for fear of the 
report. When at last he recovered speech, Sir Bors begged the old man to show him his brother's body, if dead he was, in order that he might bury him with honor and respect as befitted the nobility of his race and his own good deserts. 'Look yonder', said the old man, 'to see what you behold.' Sir Bors looked, and saw a dead body lying prostrate before him, freshly wounded and bleeding, as if it had that hour met death; and it seemed to Sir Bors that Sir Lionel's form was upon it. Sorrow and grief again came upon Sir Bors at the sight, so that he fell in a faint and a death-swoon upon him, and for a long time he lay stretched on the ground like any other dead body. After he arose from this swoon he asked the old man who had killed Sir Lionel, in order to avenge him, and he did not tell him. Sir Bors began to lament greatly for his brother, and it is this that he said: 'Alas, Lionel, dear brother and beloved companion, it was sad for thee to leave me alone, for thou wert my defender in every dangerous conflict, and thou wert my faithful protector in the king's castles when we went on a course of military service from the city of Camelot into the bounds of a strange race; so that it was the parting of soul from body to me to be separated from thee so long as we both were alive; and from the day when thou didst leave me, I have had no care but for the saving of my soul from this time forth!' After this Sir Bors raised the body in his two hands and laid it on the covering of the horse, and asked the old man to direct him to some monastery in which he might bury his brother's body. The old man told him there was a small oratory in the neighborhood, and there was page.]

[Here the fragment abruptly ends at the bottom of the

\section{Second Fragment.}

(page 1) ' - [cin-]iudha ${ }^{1}$ ) dóendai ; 7 is e an crann etoir tech forsa raibhe i. an sægul roboi cen credem cin riaghail ecalsa riann-gein Crist, acht sil Adhaim uile ic dul an ifern a cinaidh a sinnser, uair rop iat-sein na h-eoin marbha co ro doirt

1) The bracketed letters probably stood on the previous page. The word, which Nettlau restored, is made practically certain by the recurrence of in ciniudh doendai below on page 388 . 
in t-en uasal i. Isu Crist, a fhuil isin croich cesta dia taithbeodhadh, uair atbathatar a n-Adham fri remius chóic n-aimser cósin. Occus ro taispen duit-si isin cruth-sin he fein ar daigh nach beath grain na adhuath ocat-sa fri fulang bais 7 trebhlaiti dar a cenn-som, amal ro fhulaing-séin dar do cenn-sa. Occus asa h-aithli-sein ro sheol tu airmb i $m$-boi in righan óc ica raibi righe Amans ${ }^{1}$ ) ica buain ar ecin di icon $t$-sienrighain. Is í righan oc tuicther indsin ica h-indarbadh icon t-senrigain i. in eclais noeb fil ica h-inghreim do gres. Occus fos is $\mathrm{i}$ an t-senrighan i. in senrecht ro boi isin domhan ria $n$-gein Crist, uair atá-sein cech lai ic fortamlugudh forsan n-eclais noib conid airi-sein ro fhóidh in coimdhis ${ }^{2}$ ) tusa do cathachudh dar cen $n$ na h-ecalsa do gres. Occus ro accain in ríghan oc frit-sa in anforlann rohimredh fuirri 7 ro gabais do laim a cobair 7 a furtacht amal badh accmaing duit; 7 is amhlaidh tainic cucat fós an erradh dorchai i. i fhigair cumhadh 7 tuirsi. Is amlaidh sin bis an eclas co $m$-bron 7 accaine n-dermair ic cuingidh díghla do gres for lucht a saraighthi, uair is clann spirutallai don eclais noib in cinuidh doéndai uili cen co-p anoir 7 airmitiu mathar doberat di. Rogabh baigh 7 coinnircle tu-sa frisin righain oig la mét in amfhorlainn ro h-imredh furri. Is amlaidh-sin atái frisin n-eclais, uair cech ecen 7 cech doccomail itchí furre is erlam tu-sa dia cobair, a Sir Boos', ol in t-ap.

'An da én itchondarcais fos isin aisling $i$ ', olsé, 'ata ni aile is coir do tucsin estib. An t-en dubh cetus ro raidh frit, ciar bo solus taitnemach dellrad in eoin aile nir ba h-uaisle a gnimha oldaat a gnima uadein; is e-sein Isu Crist, uair ciar bo bocht dereoil a shéta isin bith freccnaircc i fus, is lethan 7 is fairsiung ${ }^{3}$ ) iat fadeoigh $\mathrm{i}$ fhlaithes nimhea i $n$-oentaidh na noeb trinnoiti, Athar 7 maic 7 Spiruta Noib. Occus fos', olse, 'ciar bo dereoil inisel nech isin t-sægul, bidh moiti a anoir 7 a airmitiu illeth fri Dia. Is e in t-én gel tainic cucat fos', ol in t-ap, 'i

1) Cf. the French: 'la dame a qui li rois amans auoit baillie sa terre a garder'. The name in Malory is 'King Aniaus'.

2) Read coimdhiu or coimdhid? Or perhaps coimsid?

s) There seems to be a reminiscence of scriptural language here. Cf. Atkinson, Passions and Homilies, p. 152: 'Is ac aisneis in t-séta-sin atberar is-in scriptúir: is lethan 7 is fairsiung in sét idnaices na heccraibdechu cos-in malairt 7 cus-in etarthuitinim suthain, cumung imorro sét na bethad doenna i comalliud thimna De'. 
cosmailes ulchobchain,1) .i. diabhal, uair cid solus taitnemach in t-ulchobchan don leith amuigh, is dubha a ghnima 7 a oibrigthi don leith astigh; conidh amlaid sein bit lucht in fhuarcrabaidh bis $^{2}$ ) ic cuingidh (page 2) a molta 0 dhainibh uair ni dlegait fiach o Dia 0 nach do doniat a sæthar. Occus in diabul itcondarcais isin aidchi, is $\mathrm{e}^{3}$ ) dorala frit isin lo i fhigair crabaidh i cosmailes fir an fhuarcrabaidh, 7 ro demnigh duit bas do brathar i. Sir Liuinel; 7 ba brec do-sum sin uair mairid sein beos; acht rop áil la diabul do brécad-sa a micredemh 7 a n-dercaine, 7 ro erail fort doridhisi faiesedain ${ }^{4}$ ) frisin righain itrubramar tuasana, 7 dia fhæmtha-su in gnim-sain no raghadh in soidech noib dit cen faicsin tria bithu, a Sir Boos', ol in t-ap, ' 70 nach dernais eim, is ed is erdalta duit, beith for burd in t-soidech noib ic caitem na fledhi ro thuiretar (?) do shobesa 7 do chaingnima fein duit i cumaidh na ridiredh $n$-uasal aile, $i$. Sir Galaad 7 Sir Persaual 7 rl -'.

'An aisling aile itcondarcais', ol in t-ap, 'fogeba a fis amal cech ni aile. An aimhidhe galair ${ }^{5}$ ) itcondarcais cen nert cen cumachta, is e-sein Sir Liuinel, uair ata din imat a peccadh 7 a dualach co ro h-ellnigedh 7 co ro truailledh he in $n$ tib, co nach coemnacair faisiti na aithrige do denam do chuinghid dilguda o Dia. Ocus in da luib uaisle itchondarcais i n-imforrun fria aroile, it iat-sin in ridire oc 7 in maigdine ${ }^{6}$ ) dorala frit-sa;

4) This departs from both Malory and the Roxburghe French text, which describe the bird as a swan: 'ki t'aparut en samblanche de chisne' (p. 167). So also the Welsh: 'yr alarch'.

2) bis is inserted above the line.

s) is $e$ is inserted above the line.

1) The translation is not literal here. I am not sure whether faiesedain can mean 'resting, staying, abiding' (cf. 0' Reilly's foisite), or is rather to be taken as the familiar foisitiu, 'confession'. The earlier episode, if we had it in its Irish form, would probably make the passage clearer. The Roxburghe French text reads: 'mais il le dist pour che qu'il te vant faire entendre a folie et a luxure'.

s) The Irish seems to differ here from the French, the Welsh, and the Morte Narthur. The French has: 'Si counient que iou te deuise la senefianche del fust pouri et des flours'. The Welsh, similarly: 'Y prenn coch drewyedic'. Malory reads: 'Also the drye tree and the whyte lylye, the drye tree betokeneth thy brother Sir Lionell'. Just before this Malory's version speaks of a 'Third foule', which 'betokeneth the strong bataille against the faire ladies which were all divels'. This does not appear in any of the other three.

o) Read maigden? 
7 is ed ba h-ail do luib dib a blath 7 a dellradh do buain don luib aile, is amlaidh-sin ba h-ail don ridire oc sin blath 7 dellradh na h-oghdhachta robui forsin maighdin do buain di; 7 amal ro thesairc in senoir noeb itrubramar in da luib for araile, 7 roleic in ainmide n-galaiv cen tarrachtain, 7 ro ráidh frit-sa condernta aithgin in neith doroine cipe tan no tecmudh frit amal dorala do-som. Doronais-si amlaidh $\sin$ in tan itcondarcais Sir Liuinel ica malairt icon dis ridire 7 in maigden ica sarachudh icon ridire; is a fhurtacht na maigdine do dechadais-si for tus, uair ro dermaitis do gradh nadura 1) for an n-grad spirutalla ro boi ocut do Dia. Nir bo comæin cen cuittechadh2) sin, uair ro shær Día Sir Liuinel 0 bás 7 ro marbait na ridiredha ro fuapair a marbadh, 7 is follus aire-sin cipe leces a furtacht 7 a cobhair illeith in coimdedh fein amal doratuis-si tæb [fri Dia] d-furtacht Sir Liuinel, conid erlam he fein fri foiridhin cech doccamhuil 7 cech ingrema lecar na leith; 7 ro imtigh Sir Liuinel iarsin andegaidh $\mathrm{a}^{3}$ ) cuidechta .i. teglach cing Artur for eoch ridiri dona ridiribh ro fhuapair a mhalairt, 7 ni cian fos co tecema frit-sa he, a Sir Boos', ol in t-ap. 'Occus fos', ol-se, 'is e in toradh itcondarcais ic fas forsna luibibh uaisli $\sin$.i. an slicht socenelach genfes for leith on ridiri 7 on maighdin sin, uair bid imda ridire croda 7 dæini særa socenelcha genfes uadha diblinaib. Occus mani badh in edrain doratais-si forru no truaillfithi iat aræn im an oghdacht [... ni] uadh buidech Dia dib 7 ni biadh sil na comarbadha dilsi dia n-es, 7 ropad if[irn ...] a crich deghinech. Is ari-sin tuicmit-ne conid mær diles Isu Crist tu-sa, uair dia $m$-bad ridire talmandai tu is e in grad nadura ${ }^{4}$ ) ro cuimnechta, 7 is e do brathair no furtachtaighfithea.'

\section{Translation.}

'- [the races] of men; and this is the barren tree upon which it was, namely, the world that was without faith and

1) nadura (or perhaps nadurdha, adj.) is a conjecture. The MS. has ${ }_{\text {.n. }}^{\text {a }}$. in both instances when the phrase occurs. The French text has: 'et meistes a redos toute naturel amour pour l'amour de ihesu crist'.

2) Is this a proverbial expression?

8) The MS. appears to have $u$.

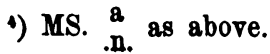


without rule of church before the birth of Christ, but the whole race of Adam going to hell on account of its ancestors; for the birds were dead until the noble bird, namely Jesus Christ, shed his blood on the cross of suffering to revive them, for they had died in Adam for the space of five ages up to that time. And he revealed himself to thee in that form in order that thou shouldst have no fear or terror at enduring death and tribulation for his sake, as he endured them for thy sake. And after this thou didst go to the place where the young queen was who held the kingdom of Amans and from whom it was being violently taken away by the old queen. By the young queen, whom the old queen attacked, is meant the holy church, which is persecuted ever. And furthermore, this is the old queen, namely the old law which was in the world before the birth of Christ; for it is every day attacking the holy church, so that on this account the Lord sent thee to fight ever on behalf of the church. And the young queen complained to thee of the violence that was used against her, and thou didst lift thy hand in aid and succor as was fitting for thee. And again it is thus that she came to thee in dark clothing, that is, in the guise of grief and sorrow. In the same way the church with sorrow and great complaint is ever asking revenge upon the people who insult her, for the whole human race are her spiritual children, but without paying her the respect and honor of a mother. Thou didst take up battle and combat for the young queen proportioned to the force that was brought against her. It is thus that thou art on the side of the church; for [in] every need and every danger that thou seest come upon her, thou art ready to aid her, o Sir Bors', said the Abbot.

'The two birds, furthermore, whom thou didst see in the vision', said he, 'there is something else to be understood by them. 'The black bird who spoke to thee first, though bright and shining the splendor of the other bird, not nobler were its deeds than the deeds [of the first]; this (i. e. the black bird) is Jesus Christ, for though poor and weak are his ways here in this present world, they are broad and spacious at last in the kingdom of heaven in the unity of the Holy Trinity, Father, Son and Holy Ghost. And furthermore', said he, 'though anyone be weak and humble in this world, the greater shall be his honor and regard with God forever. The white bird, moreover, 
who came to thee in the form of in owl', said the Abbot', is the Devil; for though the owl is outwardly bright and shining, inwardly its deeds and works are dark; and such are the hypocrites who seek praise from men, for they deserve no reward from God, since it is not for him that they do their work. And the devil whom thou didst see in the night, it is he who came to thee in the day in the guise of religion in the form of a man of hypocrisy, and announced to thee the death of Sir Lionel, thy brother; and that was a lie for him, for he [i. e. Lionel] is still alive; but it pleased the devil to deceive thee into unbelief and despair, and he enjoined it upon thee to return to the queen of whom we spoke above, and if thou hadst undertaken this deed the Holy Grail would have departed from thee without ever being seen, O Sir Bors', said the Abbot; 'and since thou didst not, truly it is destined for thee to be at the board of the Holy Grail, eating the feast which thy virtues and fair deeds obtain (?) for thee, along with the other noble knights, Sir Galahad, Sir Percival, etc.

'The other vision thou didst see', said the Abbot, 'thou shalt have knowledge of it as of everything else. The sick beast that thou didst see without force, without strength, this is Sir Lionel; for it is from the number of his sins and his vices that he has been corrupted and defiled, so that he cannot make confession or repent in order to beg forgiveness of God. And the two noble flowers that thou sawest striving with each other, these are the young knight and the maiden who came to thee; and [as] it was the desire of one of the flowers to take away the blossom and the beauty from the other, just so it was the desire of the young knight to taken away the flower and beauty of virginity that was upon the maiden. And just as the holy old man rescued the two flowers from each other, and left the sick beast without attention, and told thee that thou shouldst imitate what he had done whenever it should happen to thee as it had come to him; likewise didst thou when thou sawest Sir Lionel ill-treated by the two knights and the maiden insulted by the knight: first thou didst go to the help of the maiden, for thou didst forget thy natural (?) love because of the spiritual love that was in thee for God. That was not a favor without return, for God saved Sir Lionel from death, and the two knights were killed who sought to kill him, and it is clear from this that 
if anyone [lit. whoever] commits his aid and help to the Lord himself, as thou didst depend [on God] to help Sir Lionel, He himself is ready to help [in] every trouble and difficulty that is committed to Him. And Sir Lionel proceeded then after his company, namely, the household of King Arthur, upon the horse of one of the knights who had tried to disable him, and it will not be long before he will meet thee, 0 Sir Bors', said the Abbot. 'And furthermore', said he, 'this is the fruit thou didst see growing upon those noble plants, namely, the gentle offspring that shall be born from the knight and the maiden, for there shall be many bold knights and free, noble men who shall spring from them both. And if it had not been for the separation which thou didst make between them, thou wouldst have deprived them both at once of their purity [... and (?)] God would [not] have been pleased with them, and there would be no seed or beloved heirs after them, and [hell would be] their last abode. It is from this that we understand that thou art a beloved steward of Jesus Christ, for if thou wert an earthly knight, it is natural (?) love that thou wouldst have remembered, and it is thy brother thou wouldst save.'

Harvard University.

F. N. Robinson. 